\title{
AZ INFORMÁCIÓTECHNOLÓGIA VÁLLALATI ÉRTÉKTEREMTÉSÉNEK ELMÉLETEI, SZEMLÉLETMÓDJAI ÉS MÓDSZEREI
}

A szerzők cikkükben a vezetéstudomány számára használható, áttekintő modellt javasolnak az IT beruházások értékteremtésének értelmezésére. Ismertetik azokat a közgazdasági elméleteket, amelyek meghatározzák, hogyan épülnek fel a konkrét módszerek, majd az elméletekből szemléletmódokat vezetnek le, amelyek kijelölik a vizsgálatok mélységét és értelmezési tartományát. Vezetők számára a három legtöbbet hivatkozott és használt pénzügyi értékelési módszert nyolc kritérium alapján hasonlították össze azért, hogy az alkalmazásuk során kialakult eredmények a vezetői szempontú mérlegeléshez iránymutatást adjanak.

Az internethez kötődő új gazdasági eufória 2000-es évek eleji megtorpanásának egyik oka az a csalódás volt, amit a vállalatok információs technológiai (IT) beruházásaikkal kapcsolatban tapasztaltak. Ez a csalódás bizalomvesztéshez, majd az IT szektor 2000ben kezdődő recessziójához vezetett. Az IT szállítók ebben a megváltozott környezetben lassabb növekedési pályára kényszerültek, és sokkal szisztematikusabb vevői kapcsolatrendszert kellett kialakítaniuk, mint az internetes újgazdaság 2000 előtti aranykorában. Az 1995-2000 közötti időszakban az Egyesült Államokban például több mint 1,2 trillió dollárt költöttek információtechnológiai termékekre és szolgáltatásokra, és minden bizonnyal ez a túlköltekezési hullám azt sugallta, hogy a projektek eredménye is üzleti értéket fog hozni. A tapasztalatok viszont azt mutatták, hogy ez az eufória nem hozott magától üzleti eredményeket; a cégek alulmenedzsełték a technológiát, szűken értelmezték a bevezetési folyamatokat, hiányos elemeket tartalmaztak kontrolling rendszereik, és elavult értékelési modelleket alkalmaztak. A vállalatok komolyan csalódtak az IT eredményességre gyakorolt hatásaiban (árbevétel növelése, költségcsökkentés, piaci terjeszkedés stb.).

Ezeknek a folyamatoknak a következtében túlzott méretű kapacitások alakultak ki, sokféle rendszert és alkalmazást vezettek be. A pénzügyi vezetés ugyan- akkor egyre rövidebb megtérülési időkkel számolt, és ezért egyre rövidebb projektátfutási időket kezdett követelni. A legjellemzőbb jelenségek a következők voltak (Manyika - Nevens, 2002):

- a beruházásokat félkészen abbahagyták, mert implementációs problémák léptek fel,

- a költségek kezdtek elszaladni, és nem hoztak hozamokat,

- sok vállalat csak folyamatelemeket automatizált, és így soha nem láták meg az „end-to-end” megoldások hasznát,

- nem a legnagyobb hatású árbevétel vagy nyereségesség meghatározó területre koncentrálták a projekteket,

- az üzleti folyamatokat nem alakították át, azért, hogy kihasználják az IT igazi előnyeit.

A negatív tanulságok mellett, vannak pozitív tapasztalatok is, olyan vállalatok sikeres innovációival kapcsolatban például, mint a Dell Computers (számítógépgyártás), Charles Schwab (pénzügyi befektetések) vagy a Wal-Mart (kereskedelem). A sikeres implementációk alapvető jellemzői többek között a következők voltak:

- a szervezeti/vezetési és technológia innovációk tandemben készültek el, 
- a kommunikációs költségek nagymértékben csökkentek,

- a projektek az adott iparág kulcs sikertényezőire és termelékenységi mozgató elemeire fókuszáltak,

- a beruházások sorrendje is megfelelő volt - fokozatosan állították elő az IT képességeket,

- a tandemben készült innovációk átalakították az üzleti folyamatokat és a hozzájuk kapcsolódó szervezeteket, így maximálisan ki tudták használni az IT képességeket.

A sikeres vállalatok esetében az IT stratégia az üzleti stratégia szívében van, és ezen a szinten kezeli a technológiai választások komplexitását és a kockázatok kezelését. A tisztán költségcsökkentésre építő stratégiák nem bizonyultak elégségesnek (lásd a jóval drágább outsourcing megoldásokat); a túlzott piaci lelkesedés pedig ahogy láttuk, önmagában nem hoz árbevétel-növekedést. Így tehát üzleti szempontból az internet divathullám egyik legfontosabb tanulsága az, hogy sikeres IT bevezetésekhez az alkalmazóknak, de a szállítóknak is, pontosan meg kell érteniük azt, hogyan képes az IT valódi hozzáadott értéket hozni, nemcsak marginális hozamokat.

A probléma előtérbe kerülése miatt, számos megtérülés számítási módszert húztak elő a témával foglalkozó tanácsadó és szállító vállalatok döntéshozói, és ezekkel konferenciákon, technológiai bemutatókon sokszor szerepeltek az elmúlt időkben. Ebből kiindulva cikkünk megírására az a felismerés vezetett, hogy hiányzik a módszerek rendszerező jellegű, vezetéstudományi igényű áttekintése a hazai szakirodalomban. Másrészről pedig, a gyakorló döntéshozóknak is világosan kell érteniük a modellek működési mechanizmusát, mégpedig nemcsak „behelyettesítési képlet” szinten, hanem azok mélyebb gazdasági alapjait illetően is. Véleményünk szerint ez ugyanis lehetővé teheti azt, hogy megalapozottabb projektek induljanak, amelyekkel szemben megfelelő területeken megfelelő elvárásokat tudnak az illetékes vezetők és szakemberek definiálni.

Cikkünk első részében az IT beruházások értékelésének elméleti, szemléletmódbeli és konkrét számításait rendszerező modelljét mutatjuk be. Először azokat a közgazdasági elméleteket ismertetjük, amelyek meghatározzák, hogyan épülnek fel az IT beruházások értékét vizsgáló módszerek. Ezután az elméletekből kialakult szemléletmódokat rendszerezzük, amelyek ismerete azért lényeges, mert segítségükkel kijelölhető a vizsgálatok mélysége és értelmezési tartománya. A szemléletmódhoz kapcsolódóan áttekintettük azokat a számítási módszereket, amelyeket végül is a gyakorlatban alkalmaznak. A második részben a három legtöbbet hivatkozott és használt pénzügyi értékelési módszert hasonlítottuk össze nyolc kritérium alapján azért, hogy az alkalmazásuk során kialakult eredmények vezetői szempontú mérlegeléséhez iránymutatást nyújtsunk.

\section{Az IT erôforrások üzleti értékének meghatározásával kapcsolatos elméletek}

Az IT erőforrások üzleti értékének elméleti kereteit, vizsgálati szemléletmódjait és a gyakorlati módszereket az 1. táblázatban foglaltuk össze az áttekintett információtechnológiai és/vagy a közgazdaságtani szakirodalom alapján.

Elsőként a klasszikus mikroökonómiai elmélet, az ehhez kapcsolódó erőforrás-alapú szemlélet és az ezekre épülő jövedelmezőségi vizsgálatok eredményeit mutatjuk be. Látni fogjuk, hogy a vezetéstudományi szakirodalomban elterjedt versenyelőny elméletében gyökerező kutatások eredményei nagyon hasonlítanak ehhez a gondolati iskolához. Ebből a nézőpontból ismertetjük a mikroökonómiai termelési függvényekre épülő elemzéseket is. Ezután a tranzakciós költségek elméletét, a megbízó-ügynök elméletet,

Az IT-értékelés kapcsolódó elméleteinek, szemléletmódjainak és módszertanainak együttélése

\begin{tabular}{|c|c|c|c|c|c|c|c|c|c|}
\hline \multirow{3}{*}{ 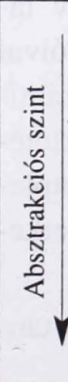 } & \multirow{2}{*}{ 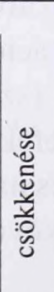 } & Elmélet & $\begin{array}{l}\text { Makroókonó- } \\
\text { miai elmélet } \\
\text { (Termelési } \\
\text { fuggvények }\end{array}$ & $\begin{array}{l}\text { Verseny- } \\
\text { elóny } \\
\text { elmélet }\end{array}$ & $\begin{array}{l}\text { Tranzakciós } \\
\text { koliseg } \\
\text { elmélet }\end{array}$ & $\begin{array}{l}\text { Megbizó- } \\
\text { ligynok }\end{array}$ & $\begin{array}{l}\text { Kónyezet } \\
\text { gazdalkodási } \\
\text { logika }\end{array}$ & \multirow{2}{*}{$\begin{array}{l}\text { Tulajdonosi érték } \\
\text { szemlélet }\end{array}$} & \multirow{3}{*}{$\begin{array}{l}\text { Reálopciós } \\
\text { elmélet és } \\
\text { értékelési } \\
\text { módszerek }\end{array}$} \\
\hline & & $\begin{array}{l}\text { Szemlélet- } \\
\text { mód }\end{array}$ & \multicolumn{2}{|c|}{$\begin{array}{l}\text { Erôforrás-alapú } \\
\text { szemléletmód }\end{array}$} & \multicolumn{3}{|c|}{ Tulajdonlás teljes költsége (TCO) } & & \\
\hline & & Módszertan & \multicolumn{2}{|c|}{$\begin{array}{c}\text { Jövedelmezőségi } \\
\text { mutatók }\end{array}$} & \multicolumn{3}{|c|}{$\begin{array}{l}\text { Diszkontált pénzáramlás } \\
\text { (DCF) alapú módszerek }\end{array}$} & $\begin{array}{l}\text { Tổkepiaci } \\
\text { reakciók } \\
\text { módszere }\end{array}$ & \\
\hline
\end{tabular}


majd egy különleges - elsődlegesen környezet-gazdaságtani célokra kidolgozott - elméleti keretet is tárgyalunk. A három elméleti kiindulás közös vonása végül a tulajdonlás teljes koncepciójához vezet, amelyen keresztül a DCF (discounted cash-flow) alapú értékelési módszerekhez jutunk. Áttekintjük a tulajdonosi érték szemlélethez kapcsolódó másik, tőkepiaci reakciókra épülő módszertant is, majd végül a reálopciókkal zárjuk teoretikus összefoglalónkat.

\section{Az IT beruházások hatása}

\section{a termelékenységre és a jövedelmezőségre}

A klasszikus mikroökonómia szerint a vállalat, egy profitmaximalizálásra törổ szervezet, amely célja elérése érdekében erôforrásokat (inputokat) alakít át kibocsátásokká (outputokká) (Kopányi, 1999). Ezen elméleti alapokon elindulva vizsgálhatjuk a vállalat által felhasznált erőforrások körét és azok hatását a termelékenységre, illetve feltárhatjuk a termelés inputoutput konverziójának függvényszerú kapcsolatait (a termelési függvényeket, ld. a következő részben). Elsőként azt mutatjuk be milyen eredményre jutottak a kutatók az IT (mint erőforrás) és a termelékenység statisztikai kapcsolatának módszeres vizsgálata során.

A kutatók eleinte arra voltak kíváncsiak, vajon mennyiben járultak hozzá a hatalmas értékủ IT beruházások a kibocsátás növekedéséhez. Már az 1970-es években is látszott, hogy az informatikai alkalmazások és a termelékenység növekedése között nincs tetten érhetổ összefüggés; a felismerés legendásan Lester Thurow-hoz, a MIT professzorához és későbbi dékánjához kötődik, aki ebben az idôszakban vezette be a termelékenységi paradoxon fogalmát. Még a „,dot-com láz" elôtt, Oliner és Sicher 1994-ben a hardver-beruházások hatását kutatta, és az IT paradoxont megerősítve azt mérték, hogy ezek hozzájárulása a növekedéshez - a kilencvenes évek elejéig - jelentéktelen volt (Oliner - Sicher, 1994). Szoftverekre kibővítve a vizsgálódási kört arra a megállapításra jutottak, hogy az IT még hardver-szoftver együttes értelmezésben sem eredményez nagyarányú output-növekedést. Sốt, ebből arra következtettek, hogy hiába növekszik az IT értékesítés világszerte, a vállalatok beruházásainak csupán kis részét fogja kitenni.

Ahogy a bevezetôben láttuk, nem lett igazuk. A vállalatok egyre nagyobb arányban fektettek be információs rendszerekbe - a kérdés csak ezek hatékonysága volt. Talán lehetne azzal érvelni, hogy - a keresletkínálat elve alapján - ha a vállalatok pénzt adnak az információtechnológiáért, akkor biztosan megéri ne- kik. Az empirikus kutatások azonban közel sem voltak ennyire egyértelműek. Voltak, akik egyáltalán nem találtak összefüggést (vagy éppen enyhe negatív korrelációt találtak) az IT befektetések mértéke és az üzleti eredményesség között - míg mások erōs pozitív kapcsolatot mutattak ki. A Thurow-féle paradoxon továbbra is erősnek látszik.

$\mathrm{Az}$ első csoportba soroltak közé tartozó Loveman 1994-ben megállapította, hogy a nem IT befektetések határhaszna meghaladja az IT befektetésekét, vagyis érdemesebb a pénzt az IT helyett másba fektetni (idézi: Barua - Kriebel - Mukhopadhyay, 1995). Épp ellenkező következtetést vonhatunk le egy másik vizsgálatból: a Brynjolfsson és Hitt által vizsgált mintán szignifikáns kapcsolat van az információtechnológiába történő tôkkebefektetés mértéke és a termelékenység között, annak ellenére, hogy ez a jelenség vállalatonként egyéni mértékben figyelhető meg (Brynjolfsson - Hitt, 2000).

Az empirikus vizsgálatok széles skálán mozgó eredményeit sokféleképpen lehet magyarázni, de legtöbben a mérési módszerek hiányosságaiban látták az alapvető okot. A pozitív eredmények hiányának oka lehet például, hogy az IT beruházások hatását legtöbben magas aggregációs szinten vizsgálták, és néhány átfogó mutatóban próbálták mérni, mint a piaci részesedés, a ROE (return on equity) vagy a ROI (return on investment). Ezek az aggregált mutatók azonban nem hủ tükrei az értékteremtési folyamatok komplexitásának és annak az összetett hatásnak, amit a „számítógépesítés” gyakorolhat rájuk (Alpar - Kim, 1990; Barua et. al., 1995).

\section{Termelési függvények és az IT, mint termelési erőforrás}

Az eddig idézett szerzők csupán az IT beruházások és a vállalatok főbb teljesítménymutatói közötti statisztikai kapcsolatot vizsgálták, mások erre építve igyekeztek az értékalkotás belső logikáját, magát a hatásmechanizmust is feltérképezni. Alpar és Kim (Alpar - Kim, 1990) ezen elemzés eszközeként a klasszikus mikroökonómiából ismert termelési függvényt választották. Ez a megközelítés az információtechnológiát termelési erőforrásként tekinti, hasonlóan a munkaerôhöz vagy a tőkéhez. Ha megtaláljuk a függvényszerū összefüggést az IT, mint input és a vállalat outputja között, akkor már könnyű számszerűsíteni az IT jövedelmezőségét. Vagyis az addícionális inputnak - jelen esetben az IT eszközöknek - a termelékenységre gyakorolt hatása az input határtermékével mérhető.

A legtöbb kutató a Cobb-Douglas termelési függvényt használva határozza meg az IT erőforrás(ok) 
határtermelékenységét. Így például Kudyba és Diwan (Kudyba - Diwan, 2002) Brynjolfsson és Hitt (Brynjolfsson - Hitt, 1996) mintáját használva megállapította, hogy az IT határterméke pozitív és időben növekvő, az eredeti elemzéshez hasonlóan pozitív, de kisebb mértékű határterméket mutat.

A termelési függvény paramétereinek konkrét meghatározása azonban a gyakorlatban nehéz, szinte lehetetlen feladat (ráadásul vállalatonként új és új kihívás), így ez az elmélet továbbra is szemléletalakító szinten maradt releváns. A figyelmet arra szeretnénk felhívni, hogy az ok-okozati összefüggések feltárása elengedhetetlen. A termelési függvény vagy az erőforrás-alapú szemlélet kiválóan alkalmas erre, a gyakorlati beruházások értékeléséhez azonban egy kevésbé elvont számszerűsítési módszerre lesz szükség. Alpar és Kim rávilágított a metódus gyenge pontjára is: nevezetesen az IT beruházásoknak azt a tulajdonságát a termelési függvény nem képes kezelni, hogy költségeik és hasznaik időben elhúzódva, nem egyszerre jelentkeznek.

\section{Versenyelőny és jövedelmezőség}

Különleges erőforrásként szemléli az IT eszközöket a versenyelőny-elmélet is, és ugyancsak az IT-tőke és a jövedelmezőség korrelációját vizsgálva próbál összefüggést meghatározni, ezt azonban más hatásmechanizmus feltételezésével teszi. A versenystratégia elmélete a Porter (1980) által megfogalmazott versenyelôny-elméletet veszi alapul. Eszerint annak ellenére, hogy egy versenyző iparágban a vállalatok hosszú távon nem tehetnek szert extraprofitra, addig rövid távon erre van lehetőség. Ennek lehetséges alapja - azaz a versenyelőny forrása - pedig lehet valamilyen egyedi input vagy képesség feletti rendelkezés. Ilyen egyedi input és/vagy képesség származhat informatikai rendszerből is, bár az IT eszközök a versenytársak számára is elérhetők, és e veszély miatt előre nem lehet megállapítani, hogy szert fog-e tenni a vállalatunk extraprofitra az IT segítségével vagy nem. Könnyen előfordulhat, hogy az IT beruházások a versenyhelyzetben egymást indukálják és „stratégiai szükségszerűséggé” válnak (Clemons, 1990 idézi: Hitt - Brynjolfsson, 1996), ahogy ezt az ezredfordulón tapasztaltuk. A pozitív példák viszont azt bizonyítják, hogy az IT innovatív használata még ebben az esetben is versenyelőny forrásává válhat, ez ugyanis már sokkal kevésbé másolható a konkurensek által. Nem szabad elfelejtkeznünk a belépési korlátok hatásáról sem: az IT ezeket tovább tudja erősíteni, de le is rombolhatja őket. (Például egy méretgazdaságossággal jelle- mezhető iparágban a termelést még hatékonyabbá tevő vállalatirányítási rendszert csak bizonyos méret felett éri meg bevezetni.)

A versenystratégiai megfontolások nem vezetnek egyértelmű eredményre, az extraprofit-termelés kétséges. Ezzel egybehangzóak a kutatási eredmények is, Hitt és Brynjolfsson (Hitt - Brynjolfsson, 1996) nem talált bizonyítékot az IT használat és a pénzügyi jövedelmezőség pozitív korrelációjára.

Hova tűnik a pozitív határtermék, miért nincs extraprofit? A szerzők nem véletlenül tartják a jövedelmezőséget a versenystratégiai nézőpont részének, ezt a jelenséget is a kettő összefüggésében vizsgálják. Sokszor a termelési hatékonyság nagymértékû növelése a belépési korlátok leépítéséhez vezet és/vagy növeli a piac vonzerejét. Ez aztán új belépőket vonz az iparágba és növeli a verseny intenzitását, ennek egyik hatása pedig az output árak csökkenése lehet. A csökkenő outputárak negatív hatását azonban már nem biztos, hogy kompenzálja a hatékonyságnövelés - a kör bezárult. Az igazi nyertesek ebben a megközelítésben a fogyasztók lesznek. Nem szabad azonban elfelejtenünk azt sem, hogy az IT projektek összehasonlítási alapja legtöbb esetben a status quonál rosszabb forgatókönyv kell, hogy legyen, így lehet, hogy a profit „nem csökkenése" már igazolja a beruházási döntést.

\section{Tranzakciós és ügynöki költségek}

A tranzakciós költségek elmélete és a megbízóügynök elmélet gyakran kerül szóba az informatikai beruházásokkal és az IT üzemeltetéssel kapcsolatban, főként a „make-or-buy” típusú döntési szituációk esetében. Mi inkább az IT beruházás értékteremtổ képességére fókuszálva igyekszünk felhasználni ezen elméletek főbb következtetéseit.

Az ügynökelmélet - a mikroökonómiától eltérően a vállalatokat nem egy profitmaximalizálásra törô, homogén piaci aktorként kezeli, hanem önérdekük által vezérelt „ügynökök” szerződéseken alapuló kapcsolatainak heterogén rendszereként (Alchian Demsetz, 1972). Az ügynökök „megbízói” a vállalat tulajdonosai, akik nemcsak céljaikban, de informáltságukban is különböznek ügynökeiktől. Míg a tulajdonosok érdeke valóban a vállalati profit maximalizálása, addig az ügynökeik általában ettől eltérô, változatos egyéni preferenciákkal és célokkal jellemezhetők. Ennek következtében az ügynökök által hozott vállalati döntések gyakran a tulajdonosok érdekeinek megfelelőek. Emellett az információs aszimmetria is nehezíti a megbízók számára ügynökeik kontrollá- 
lását: a döntésekhez szükséges információk általában az ügynökök birtokában vannak és szükség esetén általuk akár manipulálhatók is.

A megbízó-ügynök probléma megoldása az elmélet szerint a hatékony tulajdonosi kontroll, mely különböző szerződésekben, illetve monitoring rendszerben testesülhet meg. Ehhez kapcsolódnak az úgynevezett „,ügynöki költségek”, amelyek alapvetően annak költségei, hogy a megbízó folyamatosan megfigyelés alatt tarthassa ügynökeit, illetve azok munkáját. Ez jelentkezhet egy erőteljes hierarchikus kontroll költségének formájában, vagy egy bürokratikusabb, szigorú dokumentációs rendszer kiépítésének költségeként, illetve az ezek miatt kieső munkaidő alternatíva költségeként.

Itt kapcsolódik az ügynökelmélet az IT értékelésének témaköréhez: az ügynöki költségek egy része hatékonyan csökkenthető megfelelő információs rendszerek használatával. A hagyományos mikroökonómiai szemlélettel soha fel-nem-térképezhető előnyként jelentkezhet az „olcsóbb” monitoring, az időtakarékosabb dokumentációs rendszer. Ezen felül az információs aszimmetria enyhítésének is jó eszköze lehet az IT, amely betekintést engedhet a tulajdonosok számára is a cég folyamataiba, aktuális, valós és megfelelő aggregáltsági szintű információval látva el őket. Így tehát az IT az ügynöki költségek mellett csökkentheti az úgynevezett „döntési információs költségeket"(Gurbaxani - Whang, 1991) is, arra az esetre, ha centralizálnák döntési folyamataikat.

$\mathrm{Az}$ ügynök elmélettel ellentétben a tranzakciós költségek elmélete nem a vállalaton belüli, hanem a piaci kapcsolatokból indul ki - itt maga a vállalat egy alternatívát, megoldást jelent a piaci problémákra. Hiszen a piac működése sem költségmentes, a piaci aktorok közötti akcióknak is vannak úgynevezett tranzakciós költségei, amelyek a felek egymás esetleges opportunista magatartását védik ki (Hitt, 1999). A piaci tranzakciók kockázatait szintén megfelelő szerződésekkel, és az azokban megfogalmazott kontrolleszközök alkalmazásával igyekeznek csökkenteni a felek. Mivel a piaci tranzakciós költségek nagyon hasonló jellegűek, mint a vállalaton belüli ügynöki költségek, nem meglepő, hogy a rájuk gyakorolt IT hatás is hasonló. Az IT használata csökkentheti az információs aszimmetriát, szorosabb, rugalmasabb, jobban követhető és ellenőrizhető - ezáltal kisebb kockázatú - vevő-szállító együttműködést tehet lehetővé, ezáltal csökkentheti a tranzakciós költségeket.

A fenti két elmélet rávilágít az IT beruházások olyan implicit előnyeire, amelyeket esetleg az erőforrás-alapú szemlélet figyelmen kívül hagyott volna: az
1. ábra

A környezeti költségek spektruma (Molnár, 2004)

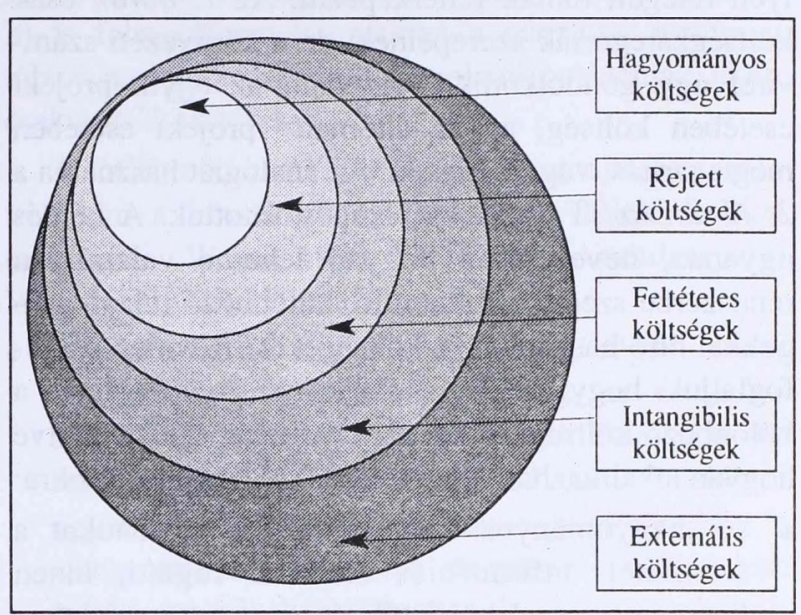

2.ábra

Az IT beruházások költség-haszon struktúrája (Molnár, 2004)

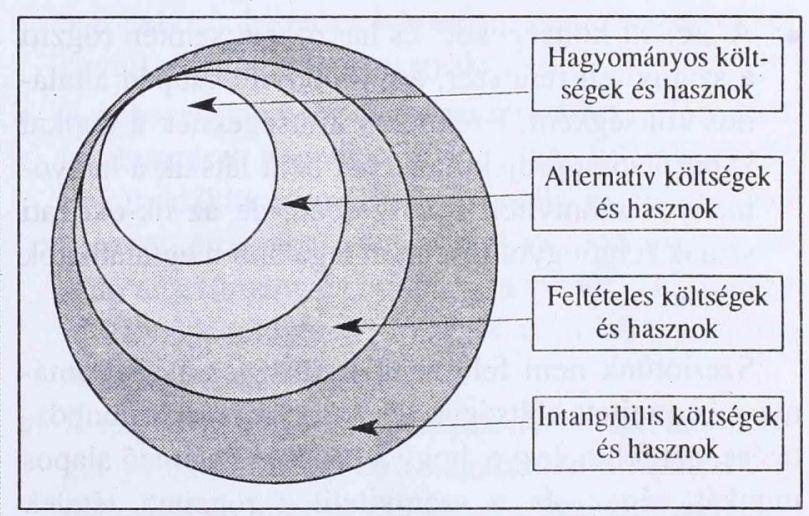

IT segít csökkenteni mind a belső koordináció költségeit (ügynöki költségek), mind a külső koordinációs költségeket (tranzakciós költségek). Ezen a gondolatmeneten továbbhaladva érdemes feltérképeznünk az IT beruházások költségeinek és hasznainak mind szélesebb spektrumát.

\section{Környezetgazdálkodási logika és a tulajdonlás teljes költsége}

Az előző szekcióban bemutatott két elmélet felhívja a figyelmet arra, hogy milyen körültekintően kell eljárnunk, amikor összegyújtjük és összevetjük egy IT beruházás költségeit és hasznait. A környezet-gazdaságtan is hasonló problémákkal küzd, mint az IT értékelése: bizonyos hasznok és költségek számszerűsítésének nehézségeivel. 
Az 1. ábra azt mutatja be, hogy a környezettechnológia értékelésekor az elemzők a költségek milyen rétegeit tudták feltérképezni. Az 1. ábrán csak költségkategóriák szerepelnek, de a környezeti számvitel úgy gondolkodik, hogy ami az egyik projekt esetében költség, az az alternatív projekt esetében megtakarítás, vagyis haszon. Az analógiát használva a 2. ábrán az IT hatásokat csoportosítottuk. A kérdés ugyanaz, nevezetesen hogyan lehetne valamilyen rendszerbe szedni a felmerülő, különböző tulajdonságokkal bíró hasznokat és költségeket? Röviden összefoglaljuk, hogy mit is ért a környezet-gazdaságtan a különböző költségszintek alatt (Molnár, 2004), illetve hogyan alkalmazható a szemlélet az IT beruházásokra:

- A „hagyományos költségeket” és hasznokat a számviteli információs rendszer rögzíti, innen könnyen visszakereshetők és az adott projekthez rendelhetők. A projekt pénzügyi vonzatainak legalább ezt a legszűkebb körét könnyen felmérheti minden értékelés.

- A ,rejtett költségeket” és hasznokat szintén rögzíti a számviteli rendszer, ám többnyire csupán általános költségként. Ezeknek a költségeknek a logikai kapcsolata a projekthez tehát nem látszik a hagyományos számviteli rendszerben, de az ok-okozati szálak felgöngyölítése után legalább megtalálhatók benne.

Szerintünk nem feltétlenül szükséges a hagyományos és a rejtett költségek (és hasznok) megkülönböztetése, azt feltételezve, hogy a pénzügyi elemző alapos munkát végez, és a számvitelileg rögzített tételek között fel tudja ismerni az összes projektelemet. Az első két kategóriát összevonhatnánk annak alapján, hogy mindegyik valós, biztosan felmerülő gazdasági eseményekhez és pénzáramlásokhoz kötődik.

- A,feltételes költségek” és hasznok jelentkezésének valószínűsége kisebb, mint 1, vagyis nem számolhatunk úgy velük, mintha mindenképpen bekövetkeznének. Így az értékeléshez ismernünk - vagy becsülnünk - kell az ezekhez a költségekhez tartozó valószínűségeket is, hiszen a valószínűség elméletének megfelelően a várható értéküket a lehetséges alternatívák valószínűségének és értékének szorzataként kapjuk meg.

- Az ,intangibilis költségek” és hasznok alatt a környezetgazdászok inkább csak a tervezési-számszerűsítési nehézségekkel terhelt jelenségeket értik, főleg a kapcsolati tőkével és vállalati imázzsal kapcsolatban. Itt azonban a továbbiakban a pénz- ügyi eredménnyel való összefüggés meghatározásának nehézségeire utalva használjuk a fogalmat, miszerint intangibilis haszon az, amelynek a cég jövedelmezőségére gyakorolt közvetlen hatása nem meghatározható.

A feltételes és intangibilis költségeknek az IT projektekben is nagy jelentőségük van, a hasznok zöme gyakran e két kategória ötvözetébe tartozik. Az információtechnológia nagy hatással lehet a vállalati mûködésre, azonban nehéz pontosan meghatározni azt a logikai láncot, ahogyan ez a hatás tovagyűrũzik a vállalaton és eljut a jövedelmezőséghez. Az informatikai beruházások értékelésének talán egyik legnagyobb kihívása az, hogy valamiképpen mégis eljussunk az intangibilis hasznok pénzértékének meghatározásához. Továbbmenve, az IT beruházások bizonytalansági szintje magas, különösen a hasznok jelentkezésének valószínűsége marad jóval $100 \%$ alatt.

- Externália (külső gazdasági hatás) akkor jön létre, amikor a gazdasági szereplők piaci ellentételezés nélkül fejtenek ki valamilyen hatást egymás tevékenységére (Kopányi, 1999). Vagyis adott projektnek lehetnek olyan (pozitív vagy negatív) hatásai is, amelyek nem a vállalatot érintik, hanem kívülállókat. Ezeket azonban az üzleti értékelésen nyugvó döntéshozatal nem veszi számításba, hiszen a döntéshozók szempontjából ezek semleges hatások - így ez hiányzik a 2. ábráról. (Lehetőség van természetesen az ilyen hatások internalizációjára és piaci alapon való kezelésére, azonban ekkor gyakorlatilag megszűnnek externáliák lenni.)

Másrészt viszont hiányoznak a modellből az olyan költségek és hasznok, amelyeket a számvitel nem rögzít, esetleg nem is kapcsolódnak valós pénzáramláshoz, azonban biztosan felmerülnek és közvetlenül kapcsolódnak a pénzügyi eredményhez (tehát nem feltételesek vagy intangibilisek). Bevezettük tehát modellünkbe az alternatív költségek kategóriáját, mert ezzel figyelembe tudjuk venni mind a tőkeköltséget, mind az adott beruházás funkcionalitásának helyettesítési költségeit, mind pedig a „nem beruházás” alternatíváját. A 2. ábrán szereplő alternatíva költség kategória tehát azokat a hasznokat és ráfordításokat reprezentálja, amelyek azáltal merülnek fel, hogy a döntéshozó egy másik költség-haszon struktúrával rendelkező alternatívát elvet, illetve attól erőforrásokat von el (Kopányi, 1999).

Az ábrák szerkezete a költségek egymásra épülését is megpróbálja szemléltetni, azt a gondolatmenetet, 
ahogy a kézenfekvő költségek számbavételétől haladunk „kifelé”, az egyre összetettebb hatások feltérképezéséig. (Az egyes kategóriák nem egymás részhalmazai, de feltételezik az előző szint figyelembevételét.)

Hasonló szemléletmóddal rendelkezik az IT értékeléssel kapcsolatban egyre többet emlegetett TCOmodell. A TCO („Total Cost of Ownership”), vagyis a tulajdonlás teljes költsége az IT beruházás, valamint a létrehozott rendszer összes közvetlen és közvetett költségét jelenti (Porgányi, 2003). A modell a kapcsolódó költségeket direkt, illetve indirekt kategóriába sorolja, ahol az indirekt csoportba tartozik például a szolgáltatásleállás vagy a végfelhasználói hozzá-nem-értés okozta munkaidő-kiesések költsége. A TCO-modell is arra próbálja felhívni a figyelmet, hogy a hagyományos számviteli beruházási költség közel sem fedi le az IT projekttel járó ráfordítások teljes körét. Emellett viszont a TCO-modell alapvetően nem terjed ki a hasznok hasonlóan széles spektrumának vizsgálatára, és nem kezeli a pénzáramlások valószínűségének problémáját sem - vagyis jóval szűkebb problémakört fed le, mint a 2. ábrán bemutatott modell.

\section{ROI és DCF}

A vállalati gyakorlatban közkedvelt megoldás az IT beruházások (és általában a beruházások) megtérülését a befektetés-arányos megtérülésük alapján mérni. A ROI - return on investment - a befektetés által termelt nettó eredmény és a befektetett összeg hányadosa, vagyis a döntéshozók által könnyen értelmezhető, egyszerű megtérülési mutató. A ROI alapvetően éves mutatószám, s mint ilyen eleve nem fejezheti ki egy eszköz ennél hosszabb élettartama alatt termelt értékét. Másrészt egy ilyen mutató számításakor hagyományosan csak a közvetlen és jól számszerűsíthetô hasznokat és ráfordításokat veszik számításba. Könnyen megragadhatnak az értékelők a számviteli kategóriákban megjelenő hasznoknál, vagy a mutató elnevezéséből kiindulva csupán a kezdeti beruházás értékét veszik figyelembe. Mindkét jelenség félrevezető lehet.

A ROI alapú értékelések mellett már elterjedtek a DCF (discounted cash flow - diszkontált pénzáramlás) alapú projektértékelési módszerek is. A DCF a projekthez kapcsolódó összes pénzáramlás várható értékét diszkontálja a jelenre egy, a projekt kockázatait is tükröző diszkontráta segítségével. A DCF már a projekt teljes időtartamára vonatkozik, és a módszer irodalma nagy hangsúlyt helyez az összes kapcsolódó költség és haszon feltárására is. Egy alaposan elkészített DCF értékelés általában számolni igyekszik a 2 . ábrán látható költség-haszon struktúra teljes körével. Itt is felmerülhetnek azonban a pénzügyi nézőpont túlzott hangsúlyozásával kapcsolatos problémák, akárcsak a ROI esetében.

A DCF módszer IT értékelési használatát a szakirodalom a következő kritikai észrevételekkel illeti (Clemons - Weber, 1990, 12-14. old.; Anandarajan Wen, 1999, 329-330. old.):

- A gyakorlatban általában az IT segítségével elérhetô költségcsökkentések képezik az értékelés alapját. Ez azonban figyelmen kívül hagyja a beruházás elmaradásának költségeit. Általában ugyanis az innovatív beruházások elmaradása a status quot megváltoztatja. Az iparági körülmények ritkán maradnak változatlanok, a versenytársak nem tétlenek - a „nem beruházás" tehát piaci pozícióvesztéshez vezethet. Vagyis a reális viszonyítási alap - alternatívaköltség - nem pusztán a jelenlegi helyzet, hanem a lehetséges piaci veszélyekkel együtt vizsgált jelenlegi gyakorlat.

- A nehezen mérhetô és számszerűsíthető előnyöket az elemzések legtöbbször figyelmen kívül hagyják, holott értékük nem feltétlenül nulla. Itt főleg olyan nehezen értékelhető hatásokról van szó, mint a javuló teljesítmény és minőség, a versenyelőny vagy új üzleti lehetőségek - vagyis az előző fejezetben említett intangibilis hatások.

- A nagy kockázat kompenzálásaképp a tőkeköltséget gyakran túlságosan magasan határozzák meg, magasabban mint az valójában szükséges lenne. De a problémát arról az oldaláról is megfoghatjuk, hogy eleve nagyon nehéz egy IT projekt tőkeköltségét meghatározni a sokféle kockázati tényező és nagyfokú bizonytalanság miatt.

- Az informatikai beruházások túlságosan komplex problémák, és ez a DCF keretei között nehezen kezelhetô.

Ezeknek a pontatlanságoknak az eredőjeként az informatikai projektek értékét általában alulbecslik (Kumar, 2002). Az első jellegzetesség a valóságosnál alacsonyabb alternatívaköltségek becslését eredményezi, és a mérési és számszerűsítési problémák is inkább a hasznokra jellemzőek, mint a költségekre. Könnyen lehetséges tehát, hogy egy ilyen nagyvonalú DCF elemzés félrevezeti a döntéshozókat, és sok IT innováció elutasításához vezet. Hasonló jelenséget tapasztalhatunk a kutatási-fejlesztési projektek esetében 
is: vagyis a DCF alapú értékelés a $\mathrm{K}+\mathrm{F}$ budget megkurtítását és a versenyképesség romlását okozta sokhelyütt az amerikai iparban (Hayes - Garvin, 1982).

A fentiekben megfogalmazott problémák valójában nem érintik a DCF módszertanát, csupán a gyakorlati alkalmazások felületességét illusztrálják. Még a fenti kritikákat megfogalmazó kutatók is a DCF mellett teszik le a voksukat, ők sem tudnak igazán jobb módszertant ajánlani, csupán kiegészíteni azt. A következő javaslatokkal igyekeznek a DCF metodológiát az IT projektek ,testére szabni” (Anandarajan - Wen, 1999, 331. old.):

1) az intangibilis hasznokat is meg kell próbálni az értékelemzés részévé tenni,

2) fel kell kutatni a projekt rejtett költségeit is,

3) kiterjedt kockázatelemzést kell végezni.

A módszertan legnagyobb előnye azonban, hogy konkrét eszközt javasol a két legfontosabb probléma megoldására: az intangibilis hasznok számszerűsítésére (szakértôi megkérdezésre alapozott várhatóértékszámítás), illetve a kockázatelemzésre (érzékenységvizsgálat).

\section{Értékelés a tőkepiaci reakciók alapján}

Természetesen a kutatók is felismerték az informatikai projektek komplexitását, és voltak, akik túl akartak lépni a vállalati értéktermelő folyamat számszerűsítésének problémáján. „Gordiusi” átvágásként visszatértek ahhoz a régi közgazdaságtani alapelvhez, hogy minden annyit ér, amennyit a piacon adnak érte. Most nem a szoftver- és hardverárakat értjük ezalatt - hiszen egy bevezetési projekt nem csupán ennyiből áll. Az értékelés alapja az a megfontolás, hogy a tőzsdei befektetők mennyivel hajlandók többet adni egy vállalat részvényeiért egy nagyobb informatikai beruházás után - természetesen hatékony tőkepiacot feltételezve.

A tőzsdei hatástanulmányok gyökere a tulajdonosi érték koncepcióhoz vezet vissza. Eszerint a vállalat alapvető célja a tulajdonosi érték maximalizálása, ennek eszköze pedig a vállalat értékének növelése (Rappaport, 2002). A vállalat értékét meg lehet közelíteni két irányból is: kívülről, vagyis a piacról, illetve belülről, azaz a pénzáramlásokon keresztül. A passzív tőkepiaci befektető szemében a vállalati érték növekedését a részvényárfolyamok emelkedése testesíti meg, míg az aktív, a vállalati döntésekben részt vevő tulajdonos inkább jövőbeli pénzáramlásokban gondolkodik. A pénzáramlás alapú értékelést az előzőekben bemutatott DCF módszer képviselte, a következőkben a tőkepiaci nézőpontot mutatjuk be.
A tőkepiaci hatástanulmányok alapgondolata nagyon egyszerű: vizsgáljuk meg, hogyan reagálnak a befektetôk bizonyos bejelentésekre, vagyis milyen statisztikai összefüggés figyelhetô meg a cégek üzleti döntéseinek bejelentése és a részvényárfolyamok mozgása között. Ha a részvényárfolyam a bejelentés hatására emelkedik, akkor a befektetők pozitív értéket tulajdonítanak az adott döntésnek (változtatásnak, beruházásnak). Hayes, Hunton és Reck (2001) például az ERP rendszerek (Enterprise Resource Planning magyarul általában vállalatirányítási rendszerek) bevezetésének hatását vizsgálta a tőkepiaci reakciók tükrében. A szerzők a bevezetés bejelentésének időpontját, pontosabban annak napját és a következô napot tartották megfelelőnek a tőkepiaci reakciók mérésére. Azt találták, hogy a piac pozitívan reagál a bejelentésekre - vagyis a beruházást értéket teremtőnek gondolja. További elemzések során azt az érdekes tényt is megállapították, hogy nagy, neves ERP rendszerek (pl. SAP, PeopleSoft) esetében szignifikánsan pozitívabb a piaci reakció, mint a kisebb szállítóknál.

Azonban még egy ilyen egyszerűnek tủnő metodológia esetében is akadhatnak nehézségek. Az alapprobléma $a z$, hogy ez csak a tôzsdén megjelenő vállalatokra elvégezhetô vizsgálat, fejlett tőkepiacú országokban. Világviszonylatban ez a kisebb probléma, hiszen a nagy informatikai beruházások amúgy is a fejlett országok nagyvállalataira jellemzőek - ôk pedig többnyire részvénytársasági formában működnek. Hazánkban azonban a tőkepiac fejlettsége, hatékonysága, mérete és likviditása már önmagában is megkérdőjelezi a módszer alkalmazhatóságát. Egy másik probléma a megfigyelési időpont: Azt az árfolyamemelkedést kell-e vizsgálni, ami a beruházás bejelentésekor megy végbe? Vagy inkább a beruházás üzembe helyezésének időpontja érdekes? Esetleg a kettô közti intervallum? Végül pedig: honnan tudjuk, hogy az árfolyamváltozás valóban az IT beruházásnak köszönhetô, hogyan tudjuk azt függetleníteni egyéb tényezőktől?

A piaci reakciókra alapozott módszernek nagy előnye az, hogy az értékelést piaci tényekre alapozza, nem szubjektív, jövőre vonatkozó feltevésekre. Ez viszont egyben az ilyen értékelések hátránya is: csupán ex post következtetések megállapítására alkalmasak.

\section{Reálopciós elmélet}

A diszkontált pénzáramlás alapú értékelési módszerek már az IT projektek viszonylag sok sajátosságát képesek kezelni: az összes kapcsolódó cash-flowt, a projekt kockázatait és több éves élet- 
tartamot. Az összetett projektek futása közben azonban általában további döntési pontokkal szembesül a menedzsment - és ezeket a DCF módszer nem kezeli. A hagyományos nettó jelenérték-számítás a lehetséges pénzáramlások valószínűségekkel súlyozott várható értékével számol, vagyis nem veszi figyelembe, hogy negatív fejlemények esetén lehetőség van például a kiszállásra vagy ellenkező esetben a projekt kibővítésére. Így a hagyományos NPV általában alulbecsli a kockázatos, ámde sok opciót tartalmazó IT beruházások értékét.

A döntési fák modellje már beépíti a DCF módszerbe a döntési pontokat is, azonban így nehézkessé válik a megváltozott kockázattal módosított diszkontráta meghatározása. Ezt a problémát küszöböli ki a klasszikus opcióértékelési módszerek alkalmazása a reálopciók értékelésében: a piacon már beárazott, hasonló kockázatú értékpapírokból állít össze egy olyan portfóliót, amely kifizetéseiben megegyezik a projekt lehetséges kimeneteleivel (Copeland - Koller - Murrin, 1999). Mivel ez a módszer meglehetősen bonyolult számításokat és sok piaci információt igényel, a gyakorlatban általában különféle binominális számítási modellek alapján történik az opciók értékelése, alapvetően kockázatsemleges megközelítéssel.

Az opciók gyakorlatilag feljogosítják - de nem kötelezik - tulajdonosukat, hogy eladjanak vagy megvegyenek valamit, egy előre rögzített időpontban (vagy időintervallumban), egy előre rögzített áron. Az opció vásárlója azt a lehetőséget szerzi meg, hogy döntését későbbre halassza, amikor már több információval rendelkezik, kiküszöbölve ezzel a kockázatok egy ré- szét. Ennek a lehetőségnek a tôzsdei árucikkek esetében természetesen értéke van, ám így van ez a reál (beruházási) opciók esetében is. A klasszikus tőzsdei opciók és az IT projektekben rejlő opciók hasonlóságát és eltéréseit mutatja be a 2. táblázat.

A 2. táblázat az IT projektekben rejlő opcióknak csak egy részét vizsgálja, általában ennél több reálopció típust lehet felfedezni bennük (Brealey - Myers, 1999 alapján):

- általában létezik egy kivárási opció, vagyis a projekt indítását későbbre halaszthatjuk, amikor már több információnk van az adott technológiávál kapcsolatban (időzítési opció),

- kedvezőtlen fejlemények esetén feladhatjuk a projektet, elkerülve a további veszteségeket (kiszállási opció),

- a projekt hatáskörét/méretét szűkíthetjük vagy tágíthatjuk a későbbiek során bármikor, amikor ez tűnik előnyösnek (skála opciók),

- adott beruházással lehetőséget teremthetünk további, erre épülő, értékteremtő beruházásokra (interprojekt opciók).

Gyakorlati szempontból azonban hiába sikerül a tőzsdei opciókhoz hasonló reálopciókat azonosítanunk a projektekben, a pénzügyi opciók értékelésére kifejlesztett binomiális modellek (pl. Black-Scholes formula, Cox-Ross-Rubinstein modell) csak szigorú feltételek mellett használhatók; például csupán egy bizonytalansági tényező vagy a fix lejáratig hátralevő idő esetén. Ezek a feltételek sokszor nem teljesülnek a

2. táblázat

A tőzsdei opciók és az IT projektekben rejlő opciók összevetése (Kumar, 2002)

\begin{tabular}{|l|l|l|}
\hline Tényezók & \multicolumn{1}{c|}{$\begin{array}{c}\text { Tözsdei opciók } \\
\text { (európai típusú vételi opció) }\end{array}$} & \multicolumn{1}{c|}{ IT projekt szakaszai, mint opciók } \\
\hline Az opció megszerzése & $\begin{array}{l}\text { Ezekkel az opciókkal kereskednek, így } \\
\text { megvásárolhatók. }\end{array}$ & $\begin{array}{l}\text { Ezek az opciók elsődleges menedzsment- } \\
\text { döntések eredményeként keletkeznek. }\end{array}$ \\
\hline $\begin{array}{l}\text { Opciós (vételi) jog gyakorlása } \\
\text { esetén a vételár }\end{array}$ & $\begin{array}{l}\text { Ezt, vagyis az úgynevezett kötési árfolyamot az } \\
\text { opció vásárlásakor meghatározzák. }\end{array}$ & $\begin{array}{l}\text { Az IT projekt következő szakaszának költsége, } \\
\text { ami nem feltétlenül előre meghatározott. }\end{array}$ \\
\hline Opcióból származó érték & $\begin{array}{l}\text { A mégszerzett pénzügyi eszköz (pl. részvény) } \\
\text { értéke. }\end{array}$ & $\begin{array}{l}\text { Az IT projektbốl származó hasznok, amelyek } \\
\text { gyakran bizonytalanok, illetve további opciókat } \\
\text { tartalmazhatnak. }\end{array}$ \\
\hline Bizonytalanság & $\begin{array}{l}\text { Az opció tárgyát képező pénzügyi eszköz piaci } \\
\text { árfolyama az egyetlen bizonytalansági tényező. }\end{array}$ & $\begin{array}{l}\text { A projektből származó költségek és hasznok } \\
\text { bizonytalansága sokrétû. }\end{array}$ \\
\hline Lejáratig hátralevő idő & Az opció vásárlásakor rögzített. & $\begin{array}{l}\text { Tapasztalati úton a menedzsment által } \\
\text { becsülhető. }\end{array}$ \\
\hline $\begin{array}{l}\text { Mit veszíthetünk, ha csak később } \\
\text { élünk opciós jogunkkal? } \\
\text { (lehetóség költségek) }\end{array}$ & Elmulasztott osztalékok (részvények esetén). & $\begin{array}{l}\text { Késedelmi költségek és/vagy kiesett jövedelmek } \\
\text { a projekt csúszásának köszönhetốen. }\end{array}$ \\
\hline
\end{tabular}


Az IT-értékelés gyakorlati módszereinek összevetése

\begin{tabular}{|c|c|c|c|}
\hline Jellemzők & Mutatószámok & Diszkontált pénzáramlások & Reálopciók \\
\hline A módszer lényege & $\begin{array}{l}\text { Az IT beruházások mértéke és } \\
\text { aggregált teljesítménymutatók } \\
\text { korrelációját vizsgálja. }\end{array}$ & $\begin{array}{l}\text { A projekthez kapcsolódó összes } \\
\text { pénzáramlás várható értékét } \\
\text { diszkontálja a jelenre egy, a } \\
\text { projekt kockázatait is tükröző } \\
\text { diszkontráta segítségével. }\end{array}$ & $\begin{array}{l}\text { A piacon már beárazott, hasonló } \\
\text { kockázatú értékpapírokból állít } \\
\text { össze egy olyan portfóliót, } \\
\text { amely kifizetéseiben megegye- } \\
\text { zik a projekt lehetséges kimene- } \\
\text { teleivel. }\end{array}$ \\
\hline Időtáv & $\begin{array}{l}\text { - 1-1 év (1-1 időszak) } \\
\text { - nem kezelik a pénz idôértéké- } \\
\text { nek problémáját }\end{array}$ & $\begin{array}{l}\text { - az eszköz teljes élettartama } \\
\text { - jelenértéken számol }\end{array}$ & $\begin{array}{l}\text { - az opció élettartama } \\
\text { - beépítve az időérték kezelése } \\
\text { is }\end{array}$ \\
\hline $\begin{array}{l}\text { Figyelembe vett pénzáramlások } \\
\text { köre }\end{array}$ & $\begin{array}{l}\text { általában a számviteli köz- } \\
\text { vetlen költségek, esetleg a } \\
\text { közvetett költségek köre is }\end{array}$ & $\begin{array}{l}\text { - a hagyományos, alternatív, } \\
\text { feltételes költségek teljes köre, } \\
\text { és intangibilis is beépíthetổ }\end{array}$ & $\begin{array}{l}\text { - pénzáramlások teljes körét, és } \\
\text { a kapcsolódó döntési pontokat } \\
\text { is kezeli }\end{array}$ \\
\hline Kockázat & - nem kezelik & $\begin{array}{l}\text { megjelenik a tỏkeköltségben } \\
\text { - a pénzáramlások bizonytalan- } \\
\text { ságát valószínűségek formájá- } \\
\text { ban tartalmazza }\end{array}$ & $\begin{array}{l}\text { - alapvetően kockázatsemleges } \\
\text { értékelési módszer } \\
\text { - a pénzáramlások bizonyta- } \\
\text { lanságát valószínúségek for- } \\
\text { májában tartalmazza }\end{array}$ \\
\hline Információigény & $\begin{array}{l}\text { kicsi-közepes, könnyen kielé- } \\
\text { gíthetổ }\end{array}$ & nagy, nehezen, de kielégíthetổ & $\begin{array}{l}\text { közepes-nagy, sok esetben } \\
\text { kielégíthetetlen }\end{array}$ \\
\hline Algoritmizálhatóság & magas & közepes vagy alacsony & magas \\
\hline $\begin{array}{l}\text { Értelmezhetóség (a döntéshozó } \\
\text { számára) }\end{array}$ & könnyủ & közepes & nehéz \\
\hline $\begin{array}{l}\text { Elterjedtség gyakorlati IT } \\
\text { értékelés területén }\end{array}$ & magas & fokozatosan növekvổ & nagyon ritka \\
\hline Konkrét módszerek & $\begin{array}{l}\text { Gyakran használt mutatószá- } \\
\text { mok: ROI, ROE, ROA stb. }\end{array}$ & $\begin{array}{l}\text { DCF alapú mutatók: NPV, IRR } \\
\text { (DCF-et gyakran kiterjesztik a } \\
\text { valószínúségek szisztematikus } \\
\text { vizsgálatával, érzékenység és } \\
\text { szcenárió elemzésekkel.) }\end{array}$ & $\begin{array}{l}\text { Gyakran használt binomiális mo- } \\
\text { dellek pl.: Black-Scholes for- } \\
\text { mula, Cox-Ross-Rubinstein } \\
\text { modell. (Használható döntési fák } \\
\text { és DCF módszer ötvözete is.) }\end{array}$ \\
\hline
\end{tabular}

komplex IT projektek esetében, nem is beszélve az értékeléshez szükséges valószínűségi adatok becslésének nehézségéről. A reálopciós elmélet mégis nagyon fontos az IT értékeléshez, legalább két okból. Egyrészt a döntéshozó számára lehetővé teszi a projektek, beruházások, mint eszközökre szóló opciók halmazának vizsgálatát, és ez a szemléletmód már önmagában is segít az értékteremtés forrásainak hatékonyabb feltárásában. Másrészt a DCF módszerrel együtt, illetve azt kiegészítve pontosabb értékelést tesz lehetővé. A DCF módszerrel kiszámított nettó jelenérték-számítás még általában alulértékeli IT beruházásokat, de ha ehhez hozzáadjuk a projektben rejlő opciók értékét is, már reálisabb képet kaphatunk ezekről. Az opciók értéke ugyanis a bizonytalanság növekedésével együtt nő (Kumar, 2002), ezért a nagy bizonytalansággal jellemezhető IT befektetések esetében a rugalmasságot biztosító opciók figyelemre méltó értéket képviselhetnek.

\section{Értékelési közelítésmódok összevetése}

Az elổzőekben bemutattuk az IT beruházások értékelésével kapcsolatban meghatározó közgazdaságtani elméleteket, szemléletmódokat és különböző eredményeket felvonultató számítási módszereket. A gyakorlati döntéshozó számára azonban valószínűleg a gyakorlati értékelési módszerek közül való választás a legfontosabb. Ezért nyolc értékelési tényező mentén öszszehasonlítottuk a három legfontosabb, gyakoribb számítási módszert (3. táblázat).

Nem szabad elfeledkeznünk arról, hogy a különböző módszerek eltérô szemléletmódokban és elméletekben gyökereznek, amelyek ismerete és alkalmazása a helyes értékeléshez elengedhetetlen. Megállapíthatjuk azt is, hogy minél több tényezőt (pénzáramlást, időtávot, kockázatokat) vesz figyelembe egy-egy modell, annál nagyobb körültekintést, szakértelmet és több információt igényel a használatuk (ld. informá- 
cióigény, algoritmizálhatóság, értelmezhetőség). A 3. ábrán ezt kívántuk érzékeltetni; a mutatószámok számítása gyakorlatias, gyors, de igen leegyszerüsített képet mutat, ami azonban kisebb IT projekteknél elegendőnek bizonyulhat. Az opciós elemzés kockázatokat, időtávot és pénzáramlást is figyelembe vesz, de elvégzése komoly felkészültséget igényel, ezért inkább komplex, nagyhatású projekteknél javasolt. A DCF módszer komplexitásában középen helyezkedik el, ezért a legtöbb IT beruházásnál ennek változatai látszanak célravezetőnek.

\section{3. ábra}

\section{Az IT-értékelési módszerek összehasonlítása}

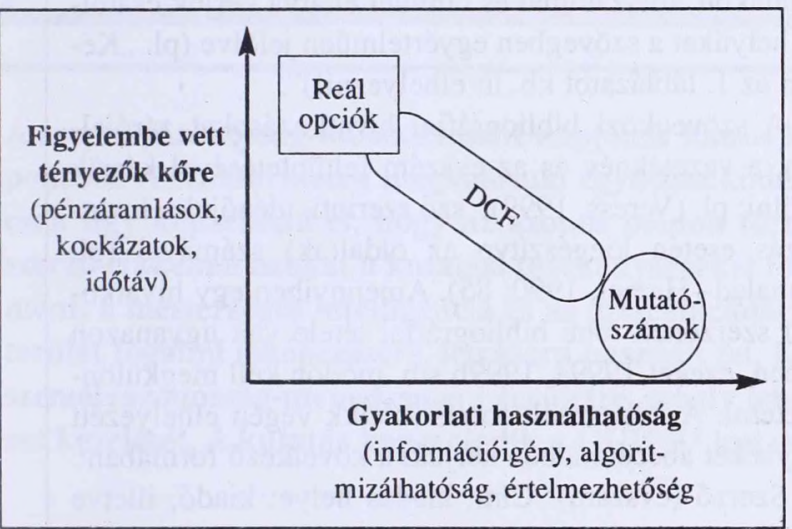

\section{Összegzés}

$\mathrm{Az}$ informatikai erőforrások vállalati értékének meghatározása az internetes lelkesedési, majd csalódási hullám után az alkalmazóknak is, és a szállítóknak is fontossá vált. Az utóbbi években megfigyelhető, hogy az IT forgalmazó cégek értékesítési és marketingstratégiájukba építették be azokat az érvéket, amelyek az informatikai hardver- és szoftvereszközök piaci hozamairól győzik meg vevőiket. A vevők ugyanakkor minél konkrétabban szeretnék ismerni és mérni a drága IT befektetések árbevételre vagy költségcsökkentésre gyakorolt hatásait.

Cikkünkben javasoltunk egy, a vezetéstudomány számára használható, áttekintő modellt az IT beruházások értékteremtésének értelmezésére. Ismertettük azokat a közgazdasági elméleteket, amelyek meghatározzák, hogyan épülnek fel a konkrét módszerek, majd az elméletekből szemléletmódokat vezettünk le, amelyek kijelölik a vizsgálatok mélységét és értelmezési tartományát. Végül ebben a kontextusban áttekintettük a gyakorlatban alkalmazott számítási módszereket, és a három legtöbbet hivatkozott és használt pénzügyi értékelési módszert összehasonlítottuk nyolc kritérium alapján azért, hogy az alkalmazásuk során kialakult eredmények vezetői szempontú mérlegeléséhez iránymutatást nyújtsunk.

Azt is reméljük, hogy áttekintésünk a pénzügy és az információmenedzsment határterületén dolgozó kollégáinknak nyújt segítséget vizsgálataik rendszerezésében, illetve a terület problémáinak további definiálásában.

\section{Felhasznált irodalom}

Alchian, A. A. - Demsetz, H. (1972): „Production, Information Costs and Economic Organisation", The Journal of Law and Economics, 22, p.233-261.

Alpar, P. - Kim, M. (1990): „A Microeconomic Approach to the Measurement of Information Technology Value", Journal of Management Information Systems, Vol. 7 No.2, p.55-69.

Anandarajan, A. - Wen, H.J. (1999): „Evaluation of information technology investment", Management Decision, Vol. 37 Issue 3/4, p.329-337.

Barua, A. - Kriebel, C. H. - Mukhopadhyay, T. (1995). „Information Technologies and Business Value: An Analytic and Empirical Investigation", Information Systems Research, Vol. 6 No. 1, p.3-23.

Brealey - Myers (1999): „Modern vállalati pénzügyek”, Panem, Budapest, II. kötet, p.79-133.

Brynjolfsson, E. - Hitt, L. M. (2000): „Beyond Computation Information Technology, Organizational Transformation and Business Performance", Journal of Economic Perspectives, Vol. 14 Issue 4, p.23-48.

Brynjolfsson, E. - Hitt, L. M. (1996): „Paradox lost? Firm-level evidence on the returns to information systems spending", Management Science, 42(4) p.541-558.

Chikán Attila (2000): „Vállalatgazdaságtan”, Aula Kiadó, Bp.

Clemons, E. K. - Weber, B. W. (1990): "Strategic Information Technology Investment: Guidelines for Decision Making", Journal of Management Information Systems, Vol. 7 No. 2, p.9-28.

Copeland, T. - Coller, T. - Murrin, J. (1999): „Vállalatértékelés”, Panem-John Wiley \& Sons, Budapest

Gurbaxani, V. - Whang, S. (1991): „The Impact of Information Systems on Organisations and Markets", Communications of the ACM, Vo1.34. No.1, p.59-73.

Hayes, D. C. - Hunton, J. E. - Reck, J. L. (2001): „Market Reactions to ERP Implementation Announcements", Journal of Information Systems, Vol. 15 Issue 1, p.3-18.

Hayes, R. - Garvin, D. (1982): „Managing as if tomorrow mattered", Harvard Business Review, 1982/May-June, p.7079.

Hitt, L. M. (1999): „Information Technology and Firm Boundaries", Information Systems Research Vol. 10, No. 2., p. 134-149.

Hitt, L. M. - Brynjolfsson, E. (1996): „Productivity, business profitability, and consumer surplus: Three different measures of information technology value", MIS Quarterly, Vol. 20 Issue 2, p.121-142.

Kopányi, M. szerk. (1999): „Mikroökonómia”, Mû́szaki Könyvkiadó, Budapest 
Kudyba, S. - Diwan, R. (2002): „Research Report: Increasing Returns to Information Technology", Information Systems Research, Vol. 13, No. 1, pp. 104-111.

Kumar, R. L. (2002): „Managing risks in IT projects: an options perspective”, Information \& Management 40., p.63-74.

Manyika, J. - Nevens M.(2002); „Technology after the bubble”, McKinsey Quarterly, Special Edition, pp. 17-27.

Molnár Ferenc (2004): „Környezeti számvitel”, Elôadás a BKÁE -en 2004.03.09-én, http://korny10.bke.hu/targyak/ vallkornyg/ marcius9ea.ppt (2004.03.20-án)ü
Oliner, S. D. - Sichel, D. E. (1994): „Computers and Output Growth Revisited: How Big Is the Puzzle?", Brookings Papers on Economic Activity, 1994 Issue 2, p.273-334,

Porgányi, G. (2003): „A TCO-modell az informatikai beruházási döntésekben", 2003.07.03., http://www.mfor.hu/cikkek/ cikk.php?article=10517, (2005.01.30-án)

Porter, M. (1980): „Competitiv Strategy”, Free Press, New York

Rappaport, A. (2002): „A tulajdonosi érték - Útmutató vállalatvezetőknek és, befektetôknek", Alinea Kiadó, Budapest

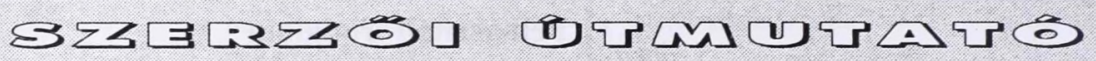

A Vezetéstudomány a Budapesti Corvinus Egyetem Gazdálkodástudományi Kar Budapesti Vezetőképző Központjának havi folyóirata. A lapban a vezetési, és tudományterületekhez kapcsolódó témakörök elméleti és gyakorlati kérdéseit elemző és vizsgáló írások jelennek meg. A szerkesztôség (robert.becsky@uni-corvinus.hu) elektronikus formában kéri az írásokat. A cikkeket elektronikus levélben vagy mágneslemezen (MS Word fájl formátumban) lehet a szerkesztőséghez eljuttatni.

A lap tudományos folyóirat, ezért szövegközi forráshivatkozások és ezek jegyzéke nélküli írásokat nem jelentet meg. A Vezetéstudományban megjelentetni szándékozott kéziratok szerzőitől az alábbi követelmények figyelembevételét kérjük:

A cikkek szokásos terjedelme a hivatkozásokkal, ábrákkal és táblázatokkal együtt 20-24 oldal, 1,5-es sortávolsággal (12-es betűméret, Times New Roman betủtípus). A cikkek első oldalának alján tüntessék fel a szerző foglalkozását, munkahelyét beosztását, és elektronikus levelezési címét, a tanulmány elkészítésével kapcsolatos információkat és az esetleges köszönetnyilvánításokat.

A kézirathoz csatolandó egy magyar nyelvû és lehetôség szerint egy angol nyelvủ rövid összefoglaló (200 szót nem meghaladó terjedelemben), valamint a cikk fő témaköreit megnevező kulcsszavak jegyzéke.

Kiemeléshez félkövér és dőlt betủ használható, aláhúzás nem. Jegyzeteket lehetőleg ne használjanak, amennyiben azok feltétlenül szükségesek, szövegvégi jegyzetként adják meg.

A táblázatoknak és ábráknak legyen sorszáma és címe, valamint - átvett forrás esetén - pontos hivatkozása. Az ábrákat és a táblázatokat a kézirat végén, külön oldalakon, sorszámmal és címmel ellátva kérjük csatolni, helyüket a szövegben egyértelműen jelölve (pl. „Kérem az 1. táblázatot kb. itt elhelyezni!)”.

A szövegközi bibliográfiai hivatkozásokat zárójelben, a vezetéknév és az évszám feltüntetésével kérjük jelölni: pl. (Veress, 1999); szó szerinti, idézőjeles hivatkozás esetén kiegészítve az oldal(ak) számával (pl. Prahalad-Hamel, 1990: 85). Amennyiben egy hivatkozott szerzőnek több bibliográfiai tétele van ugyanazon évben, ezeket 1999a, 1999b stb. módon kell megkülönböztetni. A felhasznált források cikk végén elhelyezett jegyzékét ábécérendben kérjük, a következő formában:

Szerző (évszám): Cím, kiadás helye: kiadó, illetve forrás.

1) példa (könyv): Porter, M. E. (1980): Competitive Strategy; New York: The Free Press.

2) példa (folyóirat-cikk): Prahalad, C. K. és G. Hamel (1990): The Core Competence of the Corporation; Harvard Business Review, május-június, 79-91.

A formai követelmények fentiekben érvényesített, ún. „Harvard” rendszeréről (más néven „szerző/év” vagy „név/dátum” hivatkozási módszerről) részletes tájékoztatást nyújtanak a Vezetéstudomány WEB-címén (www.bsm.hu; ,Vezetéstudomány/Szerzőinknek” menüpont) megadott források.

Havi folyóirat lévén és a megjelenés átfutási idejének csökkentése érdekében a Vezetéstudomány kefelevonatot nem küld, elfogadás előtt azonban a szerzőknek egyeztetés céljából elküldi a cikk szerkesztett változatát.

A szerkesztőség 